\title{
Ayur-Informatics: Establishing an Ayurvedic Medication for Parkinson's Disorder
}

\author{
Preenon Bagchi, Anuradha M, Ajit Kar
}

\begin{abstract}
Parkinsonism is a degenerative disorder of the Central Nervous System affecting the aged. The receptor proteins identified PARK2 and LRRK2 are modeled by modeller software. The best models selected for each receptor are selected by Ramachandran Plot analysis. Then best model selected are docked with the phytocompounds. The phyto-compounds having the best docking score are selected as the most suitable ligand and considered for further in-vitro receptor ligand binding assay studies.
\end{abstract}

Keywords--Parkinsonism, Degenerative disorder, Receptor, PARK2, LRRK2, Modelling, Docking

\section{INTRODUCTION}

Parkinson's disease (PD) is a neuro-degenerative disorder. It occurs as a result of the death of dopaminegenerating cells in the substantianigra, a region of the midbrain; the reason of this cell death is unknown [1]. The most obvious symptoms are movement-related; these include shaking, rigidity, slowness of movement and difficulty with walking and gait [2]. Later, thinking and behavioral problems arise, with dementia commonly occurring in the advanced stages of the disorder, whereas depression is the most common psychiatric symptom [3]. Other common symptoms include sensory, sleep with emotional problems. Parkinson's disease is more common in older people at age of 50 [3].

Parkinsonian cases have a genetic origin can cause neuropsychiatric disturbances which can range from mild to severe which includes disorders of speech, cognition, mood, behaviour, and thought [3].

Behavior and mood alterations are more common with or without cognitive impairment usually seen in PD with dementia [3]. Impulsive control behaviors such as medication overuse and craving, binge eating, hypersexuality, or pathological gambling can be seen in PD and have been related to the medications used to manage the disorder [4, 5, 6]. Psychotic symptoms - hallucinations or delusions-occur in $4 \%$ of people with PD [3]. It is assumed that the main precipitant of psychotic phenomena in Parkinsonism is dopaminergic excess [3]. Mutations in the SNCA (Alphasynuclein) receptor, PARK2, LRRK and AMPA ( $\alpha$-amino-3hydroxy-5-methyl-4-isoxazolepropionic acid) are noted as causal factors for Parkinsonism.

Preenon Bagchi Author is with Padmashree Institute of Management \& Sciences, Bangalore, India and Sarvasumana Association, Bangalore, India).

Anuradha M. Author is with Padmashree Institute of Management \& Sciences, Bangalore, India.

Ajit Kar Author is with Sarvasumana Association, Bangalore, India
The PARK2 gene, one of the largest human genes, expresses making a protein called parkin [7]. The official name of this gene is "Parkinson protein 2, E3 ubiquitin protein ligase (parkin)" [7]. Parkin's role is seen in the cell machinery that degrades unneeded proteins by tagging damaged and excess proteins [7]. Studies have suggested more than 200 PARK2 gene mutations causing Parkinsonism, a condition characterized by progressive problems with movement and balance [8]. Mutations in this gene are associated with the juvenile form of Parkinson disorder, which appears at very low age, on or before age 20, and some cases of the more common, late-onset form that begins after age 50 [8,9].

Leucine-rich repeat kinase 2 (LRRK2) is an enzyme that in humans is encoded by the PARK8 gene, a member of the leucine-rich repeat kinase family [10]. Variants of this gene are seen associated with Parkinson's disorder $[9,10]$. Expressions in LRRK2 mutant genes are implicated in autosomal dominant Parkinson's disease which causes shortening and simplification of the dendritic tree in vivo and in cultured neurons $[11,12]$.

For the present study the following medicinal plants have been selected to study the scope \& activity of different compounds on CNS using above mentioned bioinformatic parameter. These are:

Withaniasomnifera compounds present withanolide A and withanone

Rauwolfia serpentine compounds present Rescinnamine \& Reserpine

Hydrocotyle asiatica/Centella asiatica compound present Asiaticoside

Aloe vera compound present Kaempferol

Bacopa monnieri compounds present Apigenin \& Bacopaside I

Convolvulus pluricaulis compound present beta-sitosterol

Mucuna pruriens compound present levodopa

Ocimum sanctum compound present Eugenol

Tinospora cordifolia compound present Cordifolioside A

Curcuma longa compound present curcumin

Asparagus racemosus compounds present racemosol and rhamnose

Valeriana wallichicompounds present baldrinal and xanthorrhizol

Acorus calamus compound present Calamusenone

Nardostachys jatamansi compound present jatamanin1 
The above compounds were docked with PARK2 and LRRK2 receptor proteins.

\section{METHODOLOGY}

The Parkinsonism receptor proteins PARK2 and LRRK2 were retrieved from NCBI database (Table 1). Using BLAST search engine the templates (homologous) proteins were noted (Table 1) and downloaded from Protein Data Bank (PDB). This template was aligned with the receptor target by modeler [13] software. Again, modeler [13], with this alignment and the target receptor and the template models the tertiary structure of the receptor proteins.

The best model generated by modeller for each protein was docked with the compounds of herbal origin.

\section{RESULTS AND DISCUSSION}

PARK2: The 3d structure of PARK2 receptor is modelled using Basic Modelling module of modeller 9.10. The receptor target and the template along with their alignment were submitted to the modeller software for model generation.

Five models were generated by modeller. These models were verified by Ramachandran Plot in SAVES server (Table 2).As per the Ramachandran Plot analysis Model 4 (Fig. 1(a)) is selected as the best model since it has the most residues in the favoured region (i.e., 91.2\%) and least residues in the disallowed region (i.e. 0\%) [14].

Further docking studies [15] are done on this model.

This Model 4 is further docked (15) with different phytocompounds mentioned above (Fig. 1).

LRRK2: The 3d structure of LRRK2 receptor is modelled (13) using Basic Modelling module of modeller 9.10(13). Modeller generates the tertiary structure of the receptor based on the template and receptor-template alignment. Five models generated by modeller were verified by SAVES's Ramachandran Plot (14) (Table 4). As per Ramachandran Plot analysis Model 3 was selected as the best model since it has most residues in the most favoured region (i.e., 94.4\%) and least residues in the disallowed region (i.e., $0 \%$ ).

Model 3 is selected as the best model (Fig. 2(a)) \& further docking studies (15) are done pertaining to this model.

This Model 3 is further docked (15) with different phytocompounds mentioned above (Fig. 2).

\section{CONCLUSION}

Compounds Kaempferol, Curcumin, Bacopaside I and Beta-sitosterol having docking score of -7 and low with PARK2 receptor are selected for further receptor-ligand binding studies in-vitro.

Compounds Cordifolioside A, Bacopaside I and Withanone having docking score of -8 and low with LRRK2 receptor are considered for further receptor-ligand binding studies.

Further, it is seen that Bacopaside I is seen to have good docking score with both the receptors and hence considered the best ligand for treating Parkinsonism (after evaluation by receptor-ligand binding assay studies).

\section{ACKNOWLEDGMENT}

This work was supported by SERB-NPDF for Preenon Bagchi. Author reference number PDF/2015/000047.

\section{REFERENCES}

[1] Alexander, G.E., (2004), Biology of Parkinson's disease: pathogenesis and pathophysiology of a multisystem neurodegenerative disorder, Dialogues ClinNeurosci., 6(3):259-280.

[2] Thomas, B. and Beal, M.F., (2007) Parkinson's disease, Human Molecular Genetics, 2007, 16(2): R183-R194. https://doi.org/10.1093/hmg/ddm159

[3] Saha, A., (2013), Psychiatric morbidity in Parkinson's Disease: a case report", American Journal of Life Sciences, 1(2):27-30. https://doi.org/10.11648/j.ajls.20130102.11

[4] Djamshidian, A. and Lees, A., (2012), Impulsive Compulsive Behaviours In Patients With Parkinson's Disease Treated With Dopamine Agonists, Focus on Parkinson's Disease, 23(1):16-21.

[5] Stacy, M., (2009), Impulse control disorders in Parkinson's disease", F1000 Med Rep. 1: 29. https://doi.org/10.3410/m1-29

[6] Stacy, M., Galpern, W., Samuel, M., Lang, A., (2008), Impulse control disorders in Parkinson's disease abstract supplement, Movement Disorders, 23(9):1332-1351. https://doi.org/10.1002/mds.22147

[7] Klein, C. and Westenberger, A., (2012), Genetics of Parkinson's Disease, Cold Spring HarbPerspect Med., 2(1):1-15.

https://doi.org/10.1101/cshperspect.a008888

[8] Dauer, W. and Przedborski, S., (2003), Parkinson's Disease: Mechanisms and Models, Neuron, 2003, 39:889-909. https://doi.org/10.1016/S0896-6273(03)00568-3

[9] Rachakonda, V., Pan, T.H. and Le, W.D., (2004), Biomarkers of neurodegenerative disorders: How good are they?", Cell Research, 14:347-358. https://doi.org/10.1038/sj.cr.7290235

[10] Cookson, M.R., (2010), The role of leucine-rich repeat kinase 2 (LRRK2) in Parkinson's disease, Nature Reviews, Neuroscience, 11:791-797. https://doi.org/10.1038/nrn2935

[11] Sharma, S., Doctoral Thesis, 2010, LRRK2 Genetics And Expression In The Parkinsonian Brain, Queen Square Brain Bank, University College London.

[12] Shah, M., Doctoral Thesis, 2013, The cytoskeletal linker protein, Ezrin, inhibits $\alpha$-synucleinfibrillization and toxicity by a novel mechanism, FreienUniversität Berlin.

[13] Sali, A. and Blundell, T.L., (1993), Comparative protein modelling by satisfaction of spatial restraints" J. Mol. Biol., 234:779-815. https://doi.org/10.1006/jmbi.1993.1626

[14] Laskoswki, R.A., MacArthur, M.W., Moss, D.S.\&Thorton, J.M., (1993), Procheck: a program to check the stereochemical quality of protein structures. J. Appl. Cryst. 26:283-291. https://doi.org/10.1107/S0021889892009944

[15] Mustard, D. and Ritchie, D.W., (2005), Docking Essential Dynamics Eigenstructures",Proteins:Struct. Funct.Bioinf. 60(2):269-274. https://doi.org/10.1002/prot.20569

TABLE I TARGET \& TEMPLATE INFORMATION

\begin{tabular}{|l|l|l|l|}
\hline $\begin{array}{l}\text { Name of the } \\
\text { Disorder }\end{array}$ & $\begin{array}{l}\text { Genes } \\
\text { involved } \\
\text { (Target) }\end{array}$ & $\begin{array}{l}\text { NCBI accession } \\
\text { number }\end{array}$ & $\begin{array}{l}\text { Homologous } \\
\text { Templates }\end{array}$ \\
\hline $\begin{array}{l}\text { Parkinson's } \\
\text { Disease }\end{array}$ & & & \\
\hline & PARK2 & AAM21459.1 & 2JMOA \\
\hline & LRRK2 & NP_001238965 & 2HEIA \\
\hline
\end{tabular}


TABLE 2: RAMACHANDRAN Plot ANALYSIS OF PARK2 RECEPTORS.

\begin{tabular}{|l|l|l|l|l|l|}
\hline & $\begin{array}{l}\text { Residues in } \\
\text { most } \\
\text { favoured } \\
\text { regions }\end{array}$ & $\begin{array}{l}\text { Residues } \\
\text { in } \\
\text { additional } \\
\text { allowed } \\
\text { regions }\end{array}$ & $\begin{array}{l}\text { Residues } \\
\text { in } \\
\text { generously } \\
\text { allowed } \\
\text { regions }\end{array}$ & $\begin{array}{l}\text { Residues } \\
\text { in } \\
\text { disallowe } \\
\text { d regions }\end{array}$ & \\
\hline Model 1 & $150(88.2 \%)$ & $15(8.8 \%)$ & $5(2.9 \%)$ & $0(0.0 \%)$ & \\
\hline Model 2 & $150(88.2 \%)$ & $16(9.4 \%)$ & $2(1.2 \%)$ & $2(1.2 \%)$ & \\
\hline Model 3 & $147(86.5 \%)$ & $\begin{array}{l}19 \\
(11.2 \%)\end{array}$ & $3(1.8 \%)$ & $1(0.6 \%)$ & \\
\hline Model 4 & $155(91.2 \%)$ & $13(7.6 \%)$ & $2(1.2 \%)$ & $0(0.0 \%)$ & selected \\
\hline Model 5 & $152(89.4 \%)$ & $16(9.4 \%)$ & $2(1.2 \%)$ & $0(0.0 \%)$ & \\
\hline
\end{tabular}

TABle 3: DOCKING SCORES OF PARK2 RECEPTOR With DIFFERENT PHYTOCOMPOUNDS

\begin{tabular}{|l|l|l|}
\hline Protein name & Phytocompound & $\begin{array}{l}\text { Docking } \\
(\mathrm{kcal} / \mathrm{mol})\end{array}$ \\
\hline PARK2 & & \\
\hline & Asiaticoside & $-1.362469 \mathrm{e}+01$ \\
\hline & Kaempferol & $-8.753344 \mathrm{e}+00$ \\
\hline & Curcumin & $-8.602408 \mathrm{e}+00$ \\
\hline & Racemosol & $-6.872410 \mathrm{e}+00$ \\
\hline & Rhamnose & $-3.541415 \mathrm{e}+00$ \\
\hline & Baldrinal & $-5.647861 \mathrm{e}+00$ \\
\hline & Xanthorrhizol & $-1.483261 \mathrm{e}+02$ \\
\hline & Calamusenone & $-6.343760 \mathrm{e}+00$ \\
\hline & Jatamanin1 & $-7.489267 \mathrm{e}+00$ \\
\hline & Withanolide A & $-4.777584 \mathrm{e}+00$ \\
\hline & Withanone & $-1.112849 \mathrm{e}+01$ \\
\hline & Eugenol & $0.000000 \mathrm{e}+00$ \\
\hline & Apigenin & $-4.222974 \mathrm{e}+00$ \\
\hline & Bacopaside I & $-8.494360 \mathrm{e}+00$ \\
\hline & Beta-sitosterol & $-7.030934 \mathrm{e}+00$ \\
\hline & Levodopa & $0.000000 \mathrm{e}+00$ \\
\hline & Cordifolioside A & $-1.121967 \mathrm{e}+01$ \\
\hline & Reserpine & $-1.482751 \mathrm{e}+01$ \\
\hline & Rescinnamine & $-2.247898 \mathrm{e}+01$ \\
\hline
\end{tabular}

TABLE 4: RAMACHANDRAN PLOT ANALYSIS OF LRRK2 RECEPTORS.

\begin{tabular}{|l|l|l|l|l|l|}
\hline & $\begin{array}{l}\text { Residues } \\
\text { in most } \\
\text { favoured } \\
\text { regions }\end{array}$ & $\begin{array}{l}\text { Residues } \\
\text { in } \\
\text { additional } \\
\text { allowed } \\
\text { regions }\end{array}$ & $\begin{array}{l}\text { Residues in } \\
\text { generously } \\
\text { allowed } \\
\text { regions }\end{array}$ & $\begin{array}{l}\text { Residues } \\
\text { in } \\
\text { disallowed } \\
\text { regions }\end{array}$ & \\
\hline Model 1 & $\begin{array}{l}182 \\
(93.3 \%)\end{array}$ & $11(5.6 \%)$ & $2(1.0 \%)$ & $0(0.0 \%)$ & \\
\hline Model 2 & $\begin{array}{l}183 \\
(93.8 \%)\end{array}$ & $12(6.2 \%)$ & $0(0.0 \%)$ & $0(0.0 \%)$ & \\
\hline Model 3 & $\begin{array}{l}184 \\
(94.4 \%)\end{array}$ & $10(5.1 \%)$ & $1(0.5 \%)$ & $0(0.0 \%)$ & selected \\
\hline Model 4 & $\begin{array}{l}181 \\
(92.8 \%)\end{array}$ & $13(6.7 \%)$ & $0(0.0 \%)$ & $1(0.5 \%)$ & \\
\hline Model 5 & $\begin{array}{l}182 \\
(93.3 \%)\end{array}$ & $11(5.6 \%)$ & $1(0.5 \%)$ & $1(0.5 \%)$ & \\
\hline
\end{tabular}

TABLE 5: DOCKING SCORES OF LRRK2 RECEPTOR WITH DIFFERENT PHYTO-

\begin{tabular}{|l|l|l|}
\hline \multicolumn{2}{|c|}{ COMPOUNDS } \\
\hline Protein name & Phytocompound & $\begin{array}{l}\text { Docking } \\
(\mathrm{kcal} / \mathrm{mol})\end{array}$ \\
\hline & & \\
\hline & Asiaticoside & $-1.132464 \mathrm{e}+02$ \\
\hline & Kaempferol & $-6.314091 \mathrm{e}+01$ \\
\hline & Curcumin & $-7.170742 \mathrm{e}+01$ \\
\hline & Racemosol & $-5.517816 \mathrm{e}+01$ \\
\hline & Rhamnose & $-2.825642 \mathrm{e}+01$ \\
\hline & Baldrinal & $-5.317718 \mathrm{e}+01$ \\
\hline & Xanthorrhizol & $-1.059226 \mathrm{e}+02$ \\
\hline & Calamusenone & $-4.357682 \mathrm{e}+01$ \\
\hline & Jatamanin1 & $-6.340349 \mathrm{e}+01$ \\
\hline & Withanolide A & $-5.034937 \mathrm{e}+01$ \\
\hline & Withanone & $-9.291670 \mathrm{e}+01$ \\
\hline & Eugenol & $-4.889243 \mathrm{e}+01$ \\
\hline & Apigenin & $-4.737120 \mathrm{e}+01$ \\
\hline & Bacopaside I & $-8.485326 \mathrm{e}+01$ \\
\hline & Beta-sitosterol & $-5.055651 \mathrm{e}+01$ \\
\hline & Levodopa & $-6.879671 \mathrm{e}+01$ \\
\hline & Cordifolioside A & $-9.116786 \mathrm{e}+01$ \\
\hline & Reserpine & $-1.982779 \mathrm{e}+02$ \\
\hline & Rescinnamine & $-2.221978 \mathrm{e}+02$ \\
\hline
\end{tabular}

\section{Figures}

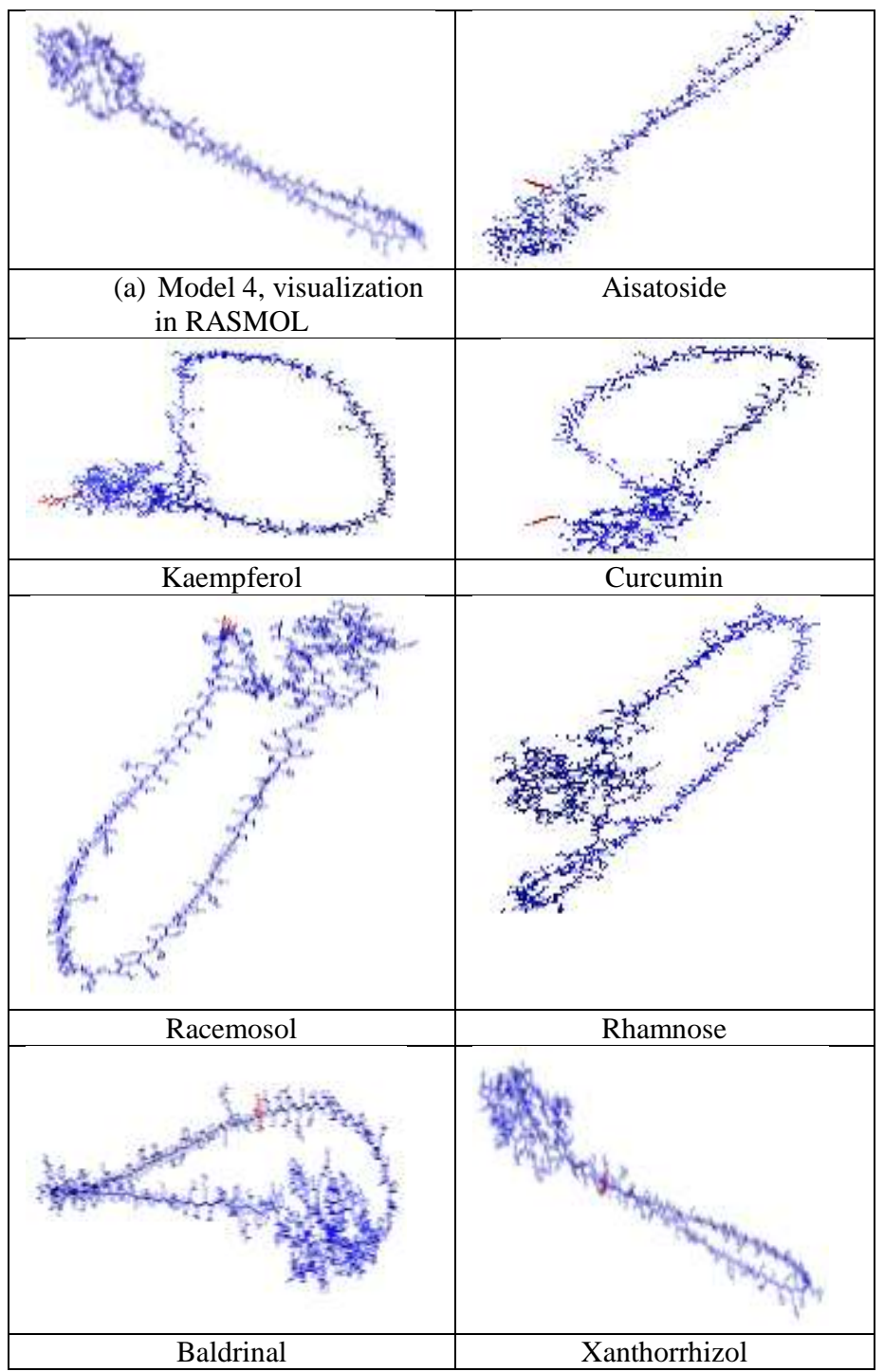




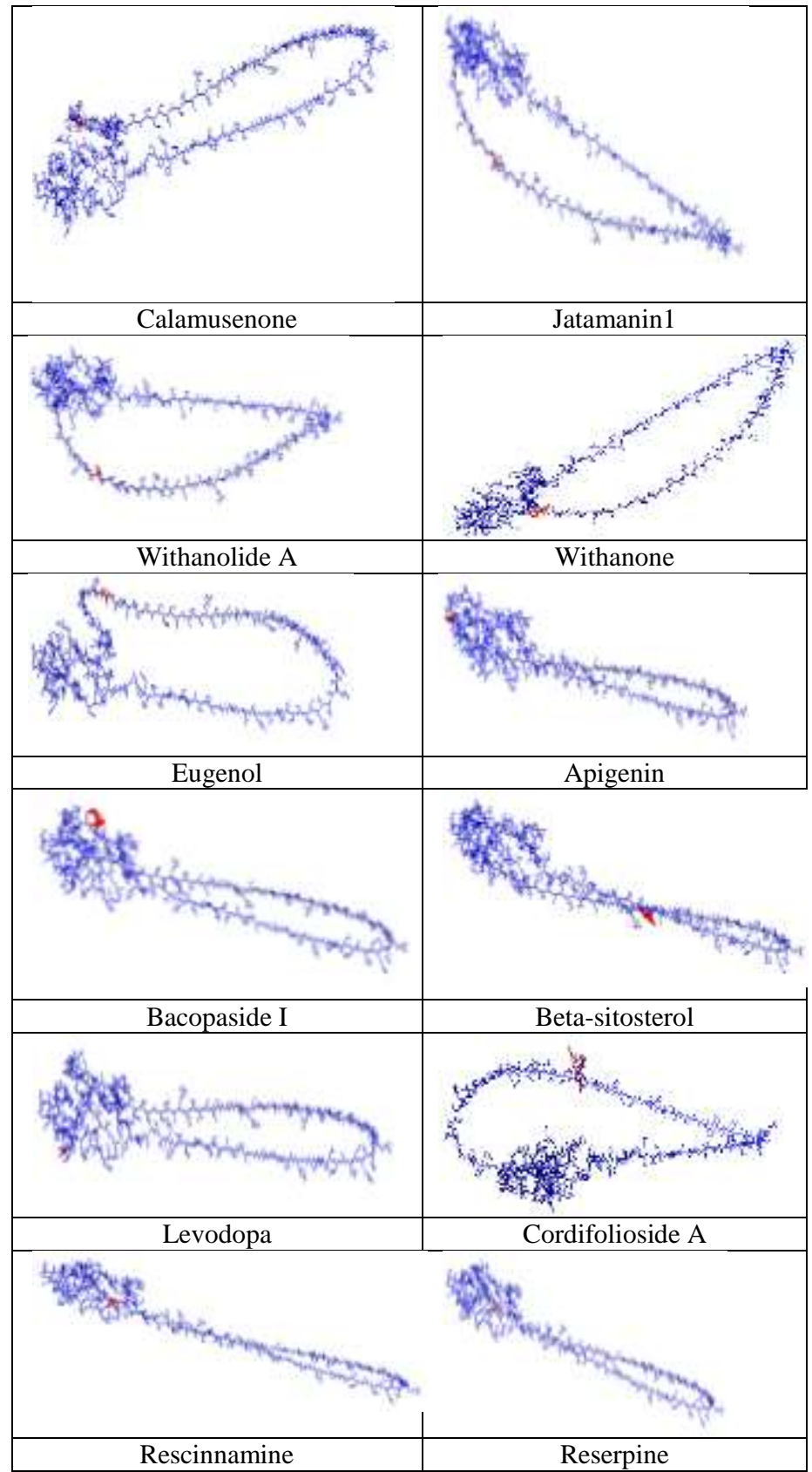

Fig. 1: Docking images (15) of PARK2 receptor with different phytocompounds.

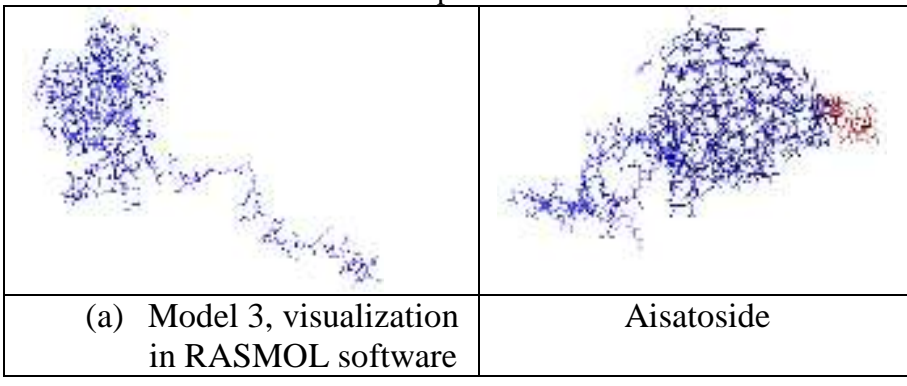

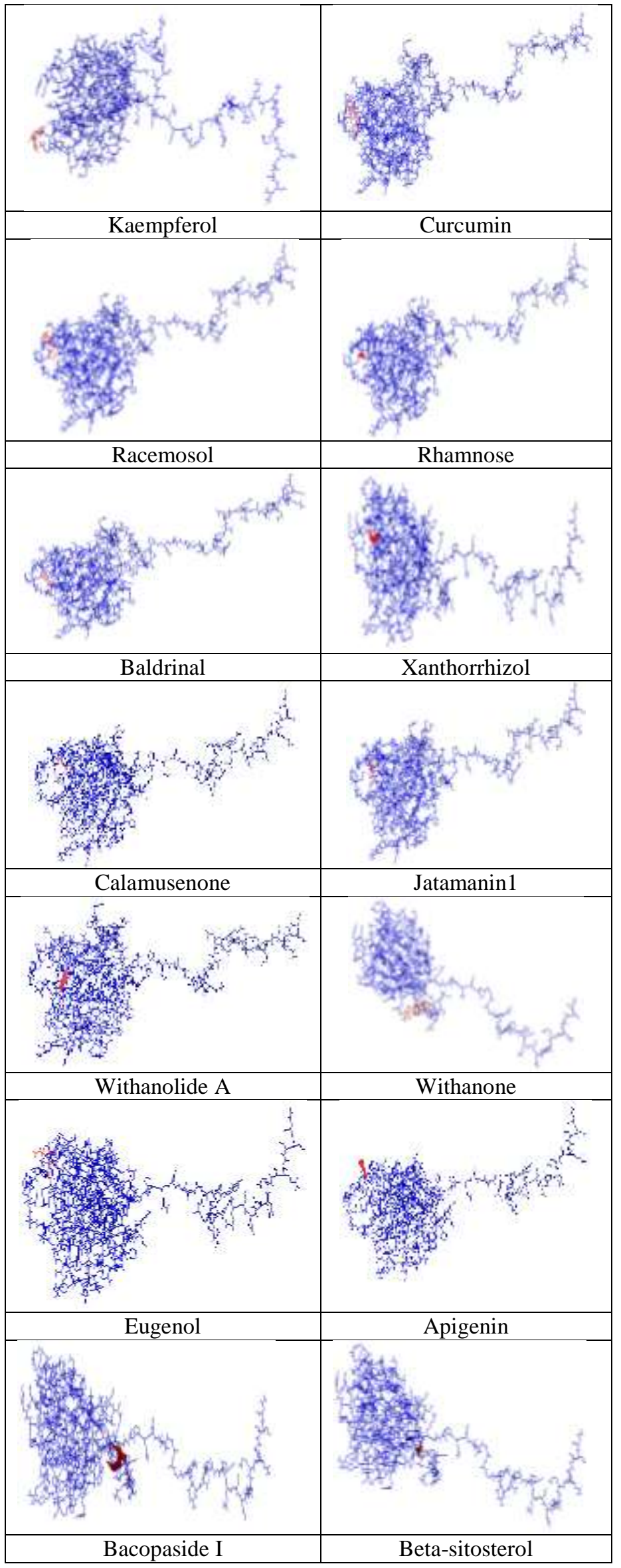




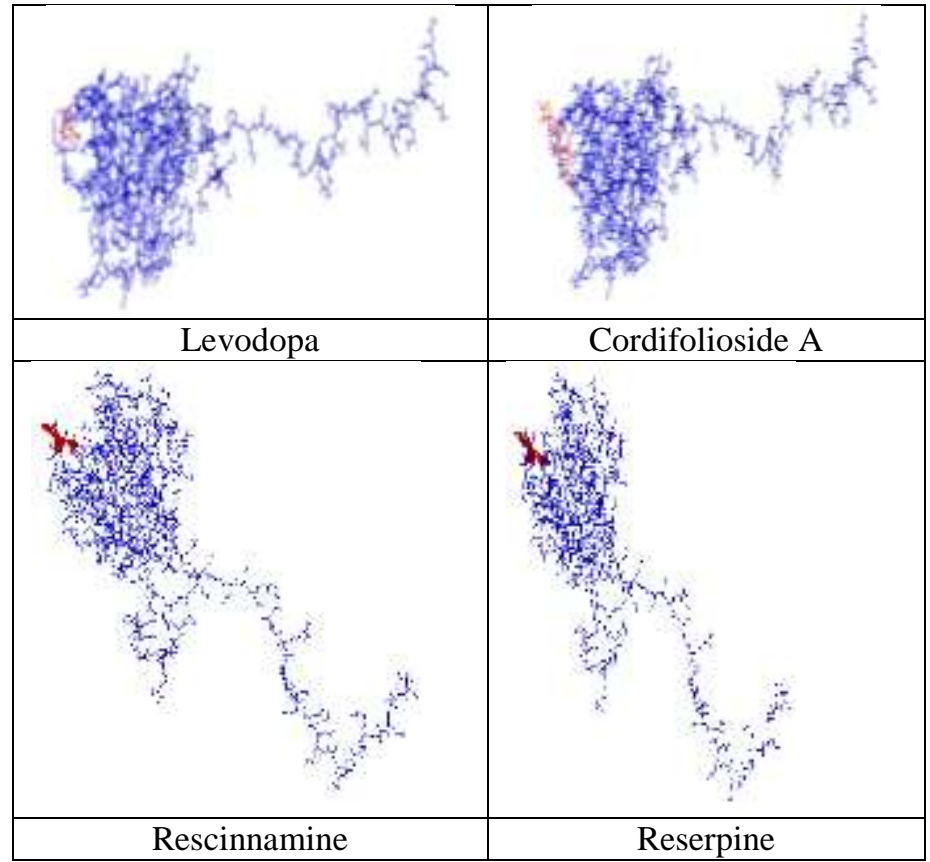

Fig. 2: Docking images (15) of LRRK2 receptor with different phytocompounds

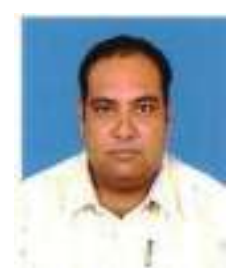

Dr. Bagchi is a Post Doctoral Fellow under Science \& Engineering Research Board, Government of India. He has done his doctorate from Career Point University, Kota, Rajasthan, India (2016). During his doctoral research he had attended IBRO sponsored Advanced School of Neuroscience at Monash University, Malaysia. He has authored over 45 research \& review papers in several national \& international journals \& in conference proceedings. He is Editorial Board Member of International Journal of Public Mental Health \& Neurosciences, The International Journal of Psychosocial and Cultural Genomics, Consciousness \& Health Research and Neuroscience Research Letters. 